\title{
Roberto Caracciolo De laudibus sanctorum kötete egy magyar prédikátor kezében
}

Roberto Caracciolo neve és prédikációs kötetei évek óta ismertek a középkori magyar irodalommal foglalkozó kutatók előtt, hiszen az Érdy-kódex egyik forrásaként tarthatjuk őt számon. Az utóbbi hónapok munkája során Roberto Caracciolo De laudibus sanctorum müvének egy olyan példányát ismertük meg, amely megerősíti a feltételezést, miszerint ez a kötet nemcsak a nyugat-európai gyakorlatban számított fontos prédikációs segédkönyvnek, hanem a Magyarországon müködő prédikátorok is merítettek a ferences barát gondolataiból. Készülő doktori disszertációmban Roberto Caracciolo sermóinak magyarországi felhasználását vizsgálom, ezért Madas Edit felhívta a figyelmemet erre a Velencében 1489-ben, Georgius Arriuabenus által kiadott De laudibus sanctorum kötetre. Ez a példány egy antikvárius tulajdonában volt, aki értékesítéshez kért véleményt a kötetben található kéziratról, majd engedélyezte annak részletes vizsgálatát. Így ismertük meg az enyhén megkopott bőrkötés és a rézcsatok maradványai mögött található páratlan kincset.

A modellsermo-gyüjtemény nyomtatott hasábjai mellett számtalan kéziratos bejegyzést találunk. Az aláhúzások, kapcsolójelek, számozások és hivatkozások kiemelése mellett számos olyan széljegyzetet olvashatunk, melyek tartalmi elemek kiemelésére utalnak. Ezek a marginálisok végigkísérik a kötetet, melynek végén a hazai prédikációtörténet egyedülálló dokumentumára bukkanunk. Írása megegyezik a széljegyzetekével. Részletes felsorolás olvasható itt arról, hogy a prédikációs kötet használója mely ünnepeken prédikált, milyen ünnepen miről beszélt, illetve, az aktuális beszédhez milyen forrásból merítette a gondolatokat. A kézirat pontosan rögzíti a jegyzetek keletkezési évét és helyét: 1495-1496, Pécs. A magyarországi használat így teljesen nyilvánvaló, de érdemes megjegyezni, hogy a felsorolt ünnepnapok között háromszor is szerepel Szent László király ünnepe. Illetve az ünnepnapokon elhangzott prédikációk felsorolásában találkozunk a következő feljegyzéssel is: „Tercia feria est Dedicacio Ecclesie Kathedralis sancti Petri Quinqueeclesiensis. Qua die predicavi de indulgenciis, vide in Tractatu de indulgenciis."

A forrás két év ünnepnapjaiba enged bepillantást. Az első ünnep 1495. június 18., Úrnapja, míg az utolsó 1496. augusztus 14., a Szent Lörinc ünnepének nyolcadába eső vasárnap. ${ }^{1} \mathrm{E}$ két dátum között természetesen nem minden ünnepnek van nyoma forrásunkban, szembetűnő azonban, hogy van olyan nap, melyet annak ellenére meg-

\footnotetext{
${ }^{1}$ Az ünnepek és pontos dátumok megfeleltetése Szentpétery Imre munkája alapján történt. SzENTPÉTERY Imre, Oklevéltani Naptár, Bp., MTA, 1912.
} 
jelöl, hogy akkor nem mondott prédikációt: „Sexta feria non predicavi quia est dies fori ea die non predicatur ex consuetudine Quinqueeclesiis." ${ }^{2}$

A rövid sermovázlatok készítője gondosan elválasztja egymástól a különböző ünnepeket, azokat nemcsak egy vízszintes, lapszéltől lapszélig tartó vonallal, hanem az ünnep pontos elnevezésének középre helyezésével is új egységként láttatja. A mintegy címszerű elhelyezés jól elkülöníti az egyházi év különböző eseményeit, így a prédikátor egy későbbi időpontban könnyen visszakereshette a korábbi beszédvázlatot. Az első olyan oldal, amelyre rövid sermovázlatokat jegyzett fel a prédikátor, az ősnyomtatvány utolsó oldala, melyen igen nagy helyet foglal el a nyomdász fametszetes jelvénye. Ezen a lapon, habár az ünnepek pontosan követik egymást, mégis több rövid és látszólag hanyag vagy utólagos jegyzetet láthatunk. A további lapokon nem jelentett gondot a feljegyzések elhelyezése, így ezek írásképe rendezettebb. A vízszintes elválasztó vonalak és a precíz külalak a mostani olvasó számára is egyértelművé teszi, hogy a prédikátor hol alkalmazott későbbi, utólagos betoldásokat a jegyzetekben. Ezek a pótlások, hozzáíások minden alkalommal a már meglévő jegyzet pontosításai, a kialakult jegyzetszerkezethez való alkalmazkodás jelei. Esetenként egy-egy, a felsorolásból kimaradt, ám mégis fontosnak tartott ünnep betoldása. Az ünnep pontos megnevezése után a thema megadása következik. A bibliai citátum a legtöbb esetben egy rövid, pár szóból álló sort jelent, mely után a bibliai helyet adja meg. Mind a citátum rövidítése, mind a bibliai hely jelzésszerủ megadása arra utal, hogy a feljegyzéseket a prédikátor saját maga, vagy más, a Szentírást igen jól ismerő olvasó számára készítette.

A prédikátor a sermovázlat elején tehát megadja azt a bibliai helyet, melyet kiindulópontként használ beszédéhez, majd megadja a sermók divisióját. Ezek néha mondatba ágyazódva jelennek meg, de a számozás segítségével minden esetben jól elkülöníti a hármas tagolást. A fó tartalmi elemek ilyen ismertetése csak akkor marad el, ha az elhangzott beszéd alapvetően egyetlen forrásra épül: „Domenica 3 in Adventu fuit festum sancte Lucie de qua predicavi Rob(ertus) De laudibus sanctorum." ${ }^{3}$

A legfontosabb gondolatok ismertetése azonban olyannyira fontos a szerzőnek, hogy nem egy olyan helyet találunk, ahol a hármas tagolás az egyetlen forrás alapján írt beszéd esetén is megtalálható, sőt utólagos betoldásként is találkozhatunk vele. Ez segítheti a visszaemlékezést egy korábban jól végigvezetett gondolatmenetre anélkül, hogy az eredeti forrást fel kellene lapozni. Aprószentek ünnepén az egyetlen megjelölt forrás Roberto Caracciolo Sermones de Adventu címü munkája, de egyértelmüen utólagos betoldásként látjuk a hármas tagolást:

1. Innocentis elongacio

2. Innocentum occisio

3. Occisorum remuneracio. ${ }^{4}$

\footnotetext{
${ }^{2}$ Robertus Caracciolus, Sermones de laudibus sanctorum, a Központi Antikvárium 117. aukciójának Katalógusa, 114. tétel, kéziratos függelék, 3.

${ }^{3}$ Uo., 2.

${ }^{4} \mathrm{Uo}$.
} 
Az eredeti forrással összevetve egyértelművé válik, hogy ez a divisio nem pusztán a Roberto Caracciolo-féle beszéd tartalmának emlékeztetője, hanem a saját beszéd pontos tagolása. Mindhárom tartalmi egység megtalálható a ferences szerző fructusában, de nem ebben a sorrendben, illetve annak a beszédnek nem ez a hármas beosztása. Így láthatjuk, hogy a compilator még abban az esetben sem egy az egyben követte a mintaprédikációt, amikor egyetlen forrásanyagból dolgozott.

A prédikáció hármas tagolásához közvetlenül kapcsolódik a beszédhez használt müvek megjelölése. Ez egyetlen esetben sem marad el. Azt gondoljuk, hogy a lista elkészítésének fö motivációja is az volt, hogy a források pontos megadásával megkímélje magát a prédikátor az újabb és újabb témakeresgéléstől. A használt müvek megadása tehát nem a hallgatóság megerősítését szolgáló auctoritas-elem, hanem a prédikátor az általa ténylegesen hozzáférhető kötetek jegyzékét adta meg. Ez az ars compilandit vizsgáló kutató számára egyedülálló dokumentum. A források alapos áttekintése tehát képet ad a korabeli prédikátor műveltségéről és egyben a lehetőségeiről is, illetve utat nyit a kompilációs technika jobb megismerésének is.

Az első és legfontosabb forrás maga az őrzőkötet, melynek hátuljába bejegyezte a prédikátor a rövid sermovázlatokat. Ez a könyv mindig a keze ügyében kellett, hogy legyen, ha ezt a kötetet választotta az év során elkészített prédikációk megörökítésére. Ezt igazolja a hivatkozások nagy száma is, összesen huszonegyszer jelöli meg ezt a könyvet forrásként. Roberto Caracciolo beszédei a korban igen népszerűek voltak, prédikációs segédkönyvei számos kiadásban terjedtek el Európa-szerte, így joggal feltételezhetjük, hogy a pécsi prédikátor számára ezek modern, újszerü beszédeknek számítottak, melyeket megismerve igen hasznos segítséghez jutott saját beszédeinek megalkotásához. Mindezek mellett mégis meglepő, hogy egy pécsi prédikátor nem csupán a legnépszerübb, legelterjedtebb Caracciolo-kötetet ismerte, hanem tulajdonképpen az összes nyomtatásban megjelent művét. A rövid sermovázlatok forrásait áttekintve ugyanis Caracciolo minden müvére találunk hivatkozást. A Quadragesimale depeccatisra hatszor (ebbőlötször De viciis címmel), a Quadragesimale de poenitentiára háromszor, a Sermones de Adventura kétszer, a De timore iudiciorum müre pedig egyszer hivatkozik. Ezek a művek mind az 1480-as évektől jelentek meg nyomtatásban, tehát láthatjuk, hogy a prédikátor igen korszerü ismeretekkel rendelkezett, illetve, hogy Roberto Caracciolo ismerete igen fontos volt a számára.

A másik legtöbbet hivatkozott kötet egy exemplumgyüjtemény. A rövid sermovázlatokból láthatjuk, hogy a beszédek igen nagy számában a divisio harmadik pontja valamiféle exemplificatio. Így érhetö, hogy a prédikátornak szüksége volt egy átfogó, részletes mutatóval rendelkező exemplumgyüjteményre. A Speculum exemplorumból huszonötször választ példázatot beszédeihez. A gyüjteményre mindig pontosan hivatkozik, az exemplumok könnyen visszakereshetőek, így a beszédeknek e tartalmi elemei pontosan azonosíthatóak.

A nagyböjt során a prédikátor részletesen feldolgozza az öt érzék témáját, napokon keresztül részletesen tárgyal egyetlen érzéket, és ezeknél a beszédeknél min- 
dig ugyanarra a müre utal a hivatkozás. Ez Nicolaus de Dinckelsbühl Tractatus de quinque sensibus címü munkája. ${ }^{5}$ A beszédvázlatok alapján úgy látjuk, hogy olyan részletességgel és alapossággal dolgozta fel ezt a könyvecskét, hogy a kötetnek mindenképpen elötte kellett lennie. Mind a nyolc esetben, amikor ebből a nyomtatványból dolgozik, a tárgyalandó téma mellé a Speculum exemplorumból vesz példát. Ez igen jól mutatja a prédikátor azon törekvését, hogy a komoly dogmatikai kérdéseket vagy elvont tanokat a nép számára érthetővé tegye. Forrásanyagunkban találkozunk olyan kötetekkel, melyek a korban igen népszerü prédikációs segédkönyvek voltak, ám modellsermóként való használatukra szinte soha nincsen utalás a kész prédikációkban. Ezen művek tartalmi vizsgálatából azonban egyértelműen kimutatható, hogy ilyen célból készültek, a fennmaradt példányok számából pedig széles körü használatukra is következtethetünk.

Ilyen például Petrus de Palude Thesaurusa, a Promptuarium exemplorum, Johannes Nider Praeceptoriuma vagy a Summa angelica. Mind a négy kötetre találunk egy-két hivatkozást, sőt a prédikátor teljesen pontosan megadja a kiválasztott részletet is. Az ezekre a művekre történő hivatkozás is azt bizonyítja, hogy a rövid sermovázlatok listáját a prédikátor saját maga számára készítette: nem bizonyító erejűnek számító auktoritásra volt szüksége, hanem tényleges forrásmegjelölésre, amely kompilációs munkáját segíti. Ezek mellett a kötetek mellett számos olyan művet láthatunk, melyre egyszer vagy csupán kétszer utal a szerző. Némely hivatkozás ezekben az esetekben is olyannyira pontos, hogy a kutató azonnal megtalálja a keresett részletet, más esetekben azonban csupán egyetlen név szerepel, melynek azonosítása már komoly nehézséget okozhat. Erre példa a leggyakrabban csak f. B.-nek rövidített szerző, akinek neve csupán egyszer szerepel a kéziratban: „Iste sermo f. B. etc. id est pruder penedek.”

A prédikációkra való felkészüléshez megjelölt kötetek tehát egytől egyig olyan nyomtatványok, melyek a korban igen elterjedtek voltak, és melyekből ma is számtalan példány lelhető fel Európa könyvtáraiban. A hivatkozások pontossága nem csupán a felhasznált szerző és mű azonosítását engedi meg, hanem a rendelkezésünkre álló nyomtatványok segítségével rekonstruálhatjuk az elhangzott beszédek tartalmát is. A compilator munkájából tehát nemcsak az anyaggyüjtés mikéntjét, a választott források korszerűségét és igényességét ismerhetjük meg, hanem a választott forrás feldolgozásának módjait is. A rendelkezésünkre álló adatok alapján háromféle használatot különíthetünk el.

Az első esetben a prédikátor egyetlen müvet vesz alapul, egyetlen mintaprédikáció alapján készíti el saját beszédét. Ebben az esetben sokszor elmarad a divisio megjelölése, hiszen a forrás megadásával a beszéd tartalmát is megjelöli. Néhány esetben azonban itt is találkozunk módosításokkal, melyek a prédikátor tudatos témaválasztását és felkészülését jelezhetik. A Circumcisio ünnepére írt beszédben a divisio meg-

${ }^{5}$ Nicolaus de Dinckelsbühl, Tractatus de quinque sensibus, Argentinae, Schott, 1516. http://reader. digitale-sammlungen.de/de/fs1/object/display/bsb10813100_00002.html. (Letöltés ideje: 2013. június 13.) 
jelöléséből érthetjük meg, hogy a prédikátor megváltoztatta a mintasermo fejezeteinek sorrendjét. Más esetben pedig a megjelölt forrás csupán egyetlen fejezetét használja fel, mint azt az alábbi példán is láthatjuk:

Item in octava s. Iohannis evangeliste que fuit in dominica Vir multum iurans implebitur iniquitate et non discedet a domo eius plaga id est divina vindicia Ecclesiasticus (Sir) 23,(12) ca.

sermo de peste 2 ca.

utrum de pestilencia sit flagellum Dei pro peccatis

quare David pocius elegit pestilenciam quam famem et gladium utrum pro peccato David debuit populus eius puniri quid intelligitur per tempus constitutum quomodo adimpletum fuit dictum prophete de pestilencia trium dierum Rob(ertus) De Iudiciis sermone XIV. capitulo tercio. ${ }^{6}$

Fellapozva a megjelölt beszédet láthatjuk, hogy a beszéd harmadik fejezete pontosan a prédikátor által is kimásolt öt részből áll: tehát ezt a fejezetet érdemesnek tartotta arra, hogy saját prédikációjaként hallják a hívek. A téma hosszúsága és kifejtettsége egy szóban elhangzó beszéd alkalmával azonban megköveteli a prédikátortól, hogy tudatos döntéssel rövidítsen a mintaprédikáción. Így az első két capitulum elhagyásával egyetlen témára összpontosít, azt azonban forrásához hasonló részletességgel tárja a hallgatóság elé.

Az egyetlen forrást feldolgozó sermókhoz közel állnak a második típusba tartozó beszédek, amikor is az alapgondolat továbbra is egyetlen forrásból származik, ám azt egy exemplummal teszi érhetőbbé a prédikátor. Erre számos példát találunk az anyagunkban, illetve ezt támasztja alá a Speculum exemplorum használatának nagy száma is, melyre fentebb már utaltam.

$\mathrm{Az}$ ars compilandit vizsgáló kutató számára a legérdekesebb a harmadik típus, amelybe azok a rövid sermovázlatok tartoznak, melyek forrásmegjelölésénél több különböző mü szerepel. Ezek a feljegyzések megörökítik a compilator fáradságos munkáját, melyre még akkor is szükség volt, amikor a szerző szóban elhangzó, egyszerübb beszédre készült, és nem írásban megjelenő mintaprédikációhoz keresett anyagot. A prédikátor tudatos választása ezeken a példákon érhető tetten a leginkább. Az In die Kathedre sancti Petri beszéd minden eleme más forrásból táplálkozik, valószínűleg egy elözetesen végiggondolt koncepció alapján, melyet a továbbiakban mutatok majd be.

In die Kathedre sancti Petri

Tibi dabo claves regni celorum Math. 16,(19) etc.

\footnotetext{
${ }^{6}$ Caracciolus, $i . m ., 2$.
} 
beati Petri dignificacio

beati Petri beatificacio

de beato Petro effectualis exemplificacio

Primum membrum sermonis Rob(erti) De laudibus sanctorum in die Apostolorum Petri et Pauli capitulo primo.

Secundum membrum invenies in sermonibus sancti Vincencii de sanctis et in sermone Apostolorum Petri et Pauli, videlicet quod beatus Petrus meruit beatificari in Paradiso celesti propter 4 virtutes.

Exemplum de beato Petro invenies in Speculo exemplorum, dist. 1. exemplo 101.

A három fejezet forrásanyagának kiválasztását akkor érthetjük meg, ha az eredeti szövegeket egymás után illesztve megnézzük, hogy miért éppen ezeket a részleteket választotta a hitszónok, és miért nem választott egy általa elérhető kész Szent Péter-beszédet. Az így létrehozott sermo igen hosszú, és bizonyos részletek ismétlődnek. A második fejezet esetében biztosra vehetjük, hogy a prédikátor csak az egyszerübb megfogalmazású változatot vette át a négy virtus leírásánál, vagyis az „ad practicam” jelzés utáni magyarázatokat. A fejezetek egymás mellé illesztéséből látjuk, hogy a hitszónok számára a fó cél Péternek mint elsőszámú apostolnak a méltatása volt, tulajdonságainak részletezése elsősorban azt szolgálja, hogy az Egyház méltóságát az ő személye is alátámaszsza. Így a Caracciolo-féle beszéd második és harmadik capituluma, melyek Pétert nem úgy méltatják, mint az Egyház fejét, hanem mint bármilyen szent életü embert, nem illenek az elözetesen elgondolt koncepcióhoz. A prédikátor ezen az ünnepen úgy tekint Péterre, mint az első pápára. Nem nézi az egyszerű halászt, a tagadó apostolt, hanem Péter minden cselekedetét és tulajdonságát abból a szempontból vizsgálja, hogy Péter az első pápa. Ehhez megfelelő anyagot talált Ferreri Szent Vince Péter-beszédében, illetve az exemplum is ezt a Péter-alakot emeli ki.

Összességében elmondhatjuk tehát, hogy egy olyan dokumentumot tartunk a kezünkben, mely az ars compilandiról eddig megszerzett ismereteinket igazolja és kiegészíti. Hiszen a rövid sermovázlatok listájából megismerhetjük, hogy mely köteteket használta valóban a prédikátor, a divisiók feltárják az elkészített sermo legfontosabb tartalmi elemeit, melyeket összevethetünk a forrásként megjelölt beszédek tartalmával, illetve ezekből megismerhetjük az összegyüjtött anyagok rendszerezését, egy kész beszéddé szervezését is.

\section{Cecilia Tóthné Radó}

Roberto Caracciolo's De laudibus sanctorum in the Hands of a Hungarian Preacher

The name and the works of Roberto Caracciolo have been well known for some time to those involved in the study of medieval Hungarian literature. He is recognised as one of the major sources for the Codex Érdy. In the past few months, we have discovered and 
examined a copy of Roberto Caracciolo's De laudibus sanctorum, which supports the argument that this collection was not only a significant work of reference in Western Europe, but it proved useful for preachers in Hungary as well. The 1489 edition of $D e$ laudibus sanctorum published in Venice by Georgius Arriuabenus features an entry that lists the various religious festivals where the owner of the volume had preached, the topics of his sermons and the sources of his inspiration. There is an explicit reference to the time and place of the entry: 1495-1496, Pécs. In my study I present and discuss this unique document which justifies and supplements what we already know in the field of ars compilandi. The short drafts for sermons reveal which reference books were used by the preacher. The divisions point out the most important themes of the sermons, which can be compared with the content of the original versions. Furthermore, we can identify the method with which the subject matter was arranged and organised into a complete sermon. 